\title{
UNWRAPPING THE SPONTANEOUS FLORA: ON THE APPROPRIATION OF WEED LABOUR
}

\author{
ÁGOTA ÁBRÁN ${ }^{1}$
}

\begin{abstract}
Part of the raw material accumulation for the medicinal plant industry in Romania is reliant on gathering plants from the so-called spontaneous flora. The imagery of medicinal plants played upon by medicinal plant product manufacturers is often abundant in visions of either wilderness or traditional peasant landscapes such as pastures. This article aims to present instead two different spaces where medicinal plants come from: wild pansy from within an oil seed rape cultivation, and elderflowers and nettles from the ruins of a former socialist orchard. These spaces of spontaneous flora highlight the process of capital's appropriation or salvage of the 'free' reproductive labour (spontaneous growth) of weeds often at odds and against other capitalist processes. Moreover, salvaging or scrounging is done through the cheap labour of a family whose livelihood depends on work both inside and outside of this capitalist process. These places, therefore, highlight the tension between the spontaneous flora and scroungers on the ground and Nature with its ancestral peasants on the supermarket and nature shop shelves.
\end{abstract}

Keywords: spontaneous flora, capital accumulation, salvage, weed labour, medicinal plant industry

\section{Nature and the spontaneous flora}

What do people see when walking down the medicinal plant isle of a supermarket or browse their way through the many nature shops that have in the past decade multiplied in cities across Romania? What is there on show on the websites and the many promotional materials and magazines of the Romanian medicinal plant product making companies? Some products and companies are advertised through clean lines and minimalist design, closely resembling pharmaceuticals and conjuring visions of white hygienic laboratories and

\footnotetext{
1 University of Aberdeen, Scotland; Centre for the Study of Modernity and the Rural World,
} Romania, e-mail: abran.agota@outlook.com. 
production facilities. Most, however, opted for an imagery filled with flowers and aesthetically arranged leaves, evoking pastures, mountains, forests, sometimes lush cultivations with neat little villages in the background. A small mini film series from Dacia Plant, for instance, entitled Plant Encyclopaedia showcases the 'Dacian' man, featuring in many of their promotional materials, dressed in seemingly traditional Dacian clothes on the back of a white horse walking through forests and teaching the viewer about the benefits of plants and their use by Dacians and Tracians, preparing cures in traditional ways (Enciclopedia Plantelor-Introducere, 2013). The same man introduces the project 'Discover Nature' (Descoperă Natura), supported by Dacia Plant, teaching kids to leave their computers and go to the school of Nature (Descopera Natura, 2013). While discovering Nature might thus seem to call for one to walk into a forest or at least a pasture, it is in supermarket isles and nature shops that one can buy natural teas, natural antibiotics, or natural vitamins and perhaps can toy with the idea that this way he or she can heal through being part of Nature just the way Dacians, peasants, or (in the case of some products) monks and nuns used to be. ${ }^{2}$

Between April 2014 and September 2015, for 18 months I have spent most of my time as an anthropologist within the diverse actors of the Romanian, mostly Transylvanian, medicinal plant industry. From collectors and cultivators, through collection centres to small and larger producers, I mapped out the movements and translations ${ }^{3}$ of plants into commodities. In this network of people, plants, and companies, Nature was often given a prominent role. Among scientists working in the medicinal plant industry such as agricultural engineers, chemists, and pharmacologists and other Romanian medicinal plant product company representatives, Nature often figured unquestioned and undefined as something one should strive to. They talked about how natural remedies are better for human bodies because they are natural, how we should spend more time in nature, how the chemicals in plants should be kept in their complexity as they are natural - sometimes even mentioning nature as that which was given by God - how Romania is abundant in natural resources, or how our ancestors knew how to use nature. Nature in these narratives is one with a capital N, an abstract form of that something outside of humans, or at least outside of some humans, that could be harnessed for human healing. ${ }^{4}$

\footnotetext{
${ }^{2}$ For an analysis of the link between traditional imagery and advertisement in Romania see Dumitrescu (2015).

${ }^{3}$ I used translation as the concept used by Latour, in that the negotiation of meanings, claims, and interests transform one thing into another $(1987 ; 2005)$.

${ }^{4}$ For a more detailed analysis of the duality of Nature and Society, their historical emergence and critique, see Haraway (2008), Latour (2004), and Moore (2015).
} 
It is to this kind of Nature - as something undefined that we do not have, are not part of but should strive to - that abstract and romantic images of Dacian shamans, Hungarian táltos ${ }^{5}$, Sekler or Romanian peasants, and Roma plant collectors were attached to. Nature, thus, was outside of only some humans, because in these narratives our ancestors, Roma, and peasants, alternatingly became part of Nature as the authentic, often 'primitive' Others. ${ }^{6}$ In these stories natural product company scientists or workers such as drivers ${ }^{7}$ would describe villagers as peasants who are similar to plants, as they cannot be rushed and are hardy and healthy; or Roma collectors as those who are home in Nature and thus - although uncivilised and could not work a 9 to 5 hour job - are the best to find plants. Contrary to these, the 'target group' of the medicinal plant industry usually those who could be described as middle-class urbanites - were seen as those who had to be saved from Society, from stressful jobs, quickened space of life, toxic food and pharmaceuticals. ${ }^{8}$ The healthy, hardy, and relaxed peasants and Roma as part of Nature were contrasted to the civilised albeit unhealthy and stressed urbanites who needed to be told to 'Discover Nature'. ${ }^{9}$

This kind of abstract Nature and abstract images of peasants and Roma, figured prominently when scientists and company representatives generally described the industry or their theories of health and human bodies to me, or when, at conferences, they argued against the use of pharmaceuticals. Similarly, the use of ethnobotanical knowledge, as the traditional plant lore of peasants was played upon by companies, although in recipe making this was always used alongside chemical research on plant compounds. As chemical compounds and traditional usage legitimised each other, information of traditional and ancient medicine was almost always attached to medicinal plants and played upon by companies. It was the idea of traditional and ancient plant lore that was capitalised on, rather than an actual gathered peasant knowledge (although sometimes this also happened). Together with such traditional peasant

\footnotetext{
${ }^{5}$ A kind of shaman; more on the resurfacing of táltos practices and neo-shamanism see Kürti (2005), Lázár (2006), and Povedák (2014).

${ }^{6}$ For diverse analyses of the Roma Other as romanticised people tied to wilderness and/or nature and a critique of how others see Roma in Europe see Bogdal (2011), Kocze and Trehan (2009), Kovács (2009), and Tong (1998). For an analysis and critique of the romantic view of the Romanian peasant see Mihăilescu (2015) and Cosma (2017).

7 Drivers would pick up plant raw materials from cultivators and collectors.

${ }^{8}$ Most of these stories were voiced at conferences that brought together the product making industry, chemists, doctors, and naturopaths.

${ }^{9}$ I am emphasising here that these are ways of talking about an abstract peasant and Roma because in actual interactions with villagers, Roma or not, such romanticism disappeared leaving often space to contempt. For such a dichotomy in how peasants are seen in Romania see also Mihăilescu (2013: 150).
} 
knowledge, monastic plant lore (see also publications from Bojor and Dumitru, 2007; Borloveanu, 2014; Chirilă and Valică, 2009) was marketed and commercialised as well.

It was these images and narratives that were present on supermarket and nature shop shelves in the forms of packaging with traditional flower designs, pictures of peasant landscapes, or abstract flower and leaf designs invoking Nature. Their labels then highlighted at every step that here you could buy natural products, opposing them in promotional materials to artificial ones such as artificial aspirin or vitamins. ${ }^{10}$ However, when scientists and company workers started to describe actual practices of working with plants, abstract concepts were replaced by ones they could work with. While Nature or what natural means in practice was taking apart into several working concepts - for instance, ecological cultivations or biodiversity rich pastures - in this article I want to focus on the concept of the spontaneous flora.

In practice, or even when describing the actual practice of plant collection, plants were never collected from an abstract Nature, rather, scientists and company workers alike would use the term spontaneous flora. I liked the term because it seemed to me that it cleverly bypassed both images of wilderness ${ }^{11}$ and rural idyll and it fitted well with the often-voiced concern of medicinal plant promoters and collectors alike, that people see collected medicinal plants as weeds. Indeed, plants that were spontaneously growing in ditches, on farms, in-between cultivations, among ruins, but even on pastures and forests, while for some were weeds, for others became medicinal plants or plants that were financially and/or medicinally valuable. Weeds seemed to be those hardy plants that would spontaneously grow anywhere and therefore collecting from the spontaneous flora made more sense than collecting from Nature. Within this then lies my fascination with the term spontaneous flora: it highlights, even acknowledges, the process of capital's appropriation or salvage of the 'free'

\footnotetext{
10 While, not the topic of this article, there can be a whole unpacking of what natural vs. artificial means in the case of these products. For instance, commercial vitamin $\mathrm{C}$ is usually, roughly explained, produced through the bacterial fermentation of glucose that makes ascorbic acid (C6H806), whereas most natural vitamin $\mathrm{C}$ products produced by Romanian companies are a mix of actual plant parts that while high in vitamin $\mathrm{C}$, as in ascorbic acid, contain a multitude of other chemical components as well. At the same time, in order to create ascorbic acid, plant bodies themselves transform glucose. For more on the complex interrelatedness of what is seen as natural as opposed to artificial in chemistry, see Bensaude-Vincent (2007), Hedley Brooke (2007), Bensaude-Vincent and Stengers (1996).

11 For an anthropological critique of the term wilderness and how it perpetuates the distinction between Nature and Society see Cassidy (2007). For ethnographies analysing how landscapes labelled as 'wild' are spaces of complex human and nonhuman influences see Lorimer (2015), Tsing (2005), Cassidy and Mullin (2007).
} 
reproductive labour (spontaneous growth) of weeds often at odds and against other capitalist processes. It is this that I will show in the following through two small examples of collecting from the spontaneous flora, not to generalise places or processes of collections, instead to catch a glimpse of how processes of accumulation make use of that which is outside of their own control.

\section{The cheap labour of spontaneous plant growth}

Before moving forward to spaces of spontaneous growth, I will introduce the idea of plant labour as part of the production of medicinal plants as commodities. Marder (2011) analyses European philosophical thinking about plants and argues that philosophers have been devaluing vegetable life in an attempt to categorise stages of life. In these 'philosophical-taxonomies' (from Plato, to Hegel, Nietzsche, and Heidegger) plants were often classified as closer to 'inanimate things' than 'other living beings' and thus transformed 'into raw materials for animal and human consumption, a "standing reserve" - in Heideggerian vernacular - on which we unreflectingly draw in order to satisfy our needs' (2011: 86). This 'ensuing instrumental approach', he argues, is what allows for such rationales as both 'deforestation and the defence of forests as "the lungs of the planet," seeing that both arguments fail to take into account vegetative life as life, aside from the external ends it might be called to serve' (2011: 88). Therefore, 'the philosophical denegation of vegetative life, ignorant of its vivacity, has had real and palpable effects on the human approach to the natural environment, so that the woods are treated as nothing more than wood, a mass of lumber "produced" in the gigantic factory of planetary proportions' (2011: 91). However, the concept of spontaneous growth brings forth the struggle of plant life to live, to grow among its surrounding environment. On the ground, it is this struggle of life and growth, not an inanimate plant, that is appropriated for production. According to Marx, in the capitalist mode of production, the exchange of commodities presupposes that they are comparable via a value that is produced by socially necessary labour time. The socially necessary labour time is an abstracted labour time that flattens out and makes all kinds of labour comparable. It shows that in the underlying process of capitalist production all labour becomes comparable through commodities being exchanged. At the same time this value does not equal the exchange value of commodities (the price they are actually sold for), nor does it equal the usevalue of commodities (what it is used for) but the three exist in relation to and within each other (Marx, 1990, I: 125-62; Harvey, 2010: 15-37). This value, as the socially necessary labour time, has a 'phantom-like' property within 
commodities, in 'the fact that the commodity reflects the social characteristics of men's own labour as objective characteristics of the products of labour themselves, as the socio-natural properties of these things' (Marx, 1990, I: 16465). In other words, when we look at commodities, we only see the thing itself, and we assume that by buying and using such commodities we enter into social relationships with the commodities, as things. However, what really happens unbeknown to us, argues Marx, is that we enter into social relations with the labourers who produced the commodity. The concept of fetishism is used because commodities appear to have a magic like property to materialise on shelves. Process is easily forgotten. While labour is hidden from sight in commodities and supermarket shelves, it is this human labour, argues Marx, that produces use-value from 'the material provided by nature' (1990, I: 133), thus labour is what mediates 'between human existence and nature' (Harvey, 2010: 27) to produce 'the physical bodies of commodities' (Marx, 1990, I: 133).

In Being Alive, Tim Ingold criticises Marx for imagining production as a process whose outcome has already been imagined by people. He argues that this image is called forth by consumption. Marx, as a materialist, had to argue for production taking precedence over the creation of its image, Ingold shows. Whereas Sahlins, also criticising Marx, as a symbolic representationist argued for the symbolic images preceding production. Ingold, on the other hand, demonstrates how both arguments fall into the dilemma of a circle of no escape between production and consumption: 'so long as we assume that there is no more to production than converting images into objects, and no more to consumption that turning objects back into images, there appears to be no escape from the circle' (Ingold, 2011: 5). But, continues Ingold, Marx himself hinted at there being more to production. That is, people as they labour not only work on the materials but transform themselves. Thus, there is something else to production in the 'attunement and responsiveness to the task as it unfolds'. This means that the ongoing process of production itself creates and changes lives. That is, the primacy of production is in its process, in life itself, 'of the processes of hoping, growing and dwelling over the forms that are conceived and realised within them'. However, if we understand production 'in its capacity literally to pro-duce, to draw out or bring forth potentials in the person of the producer and in the surrounding world', then production cannot be restricted to human beings alone. Hence, "both human and non-human, do not so much transform the world, impressing their preconceived designs upon the material substrate of nature, as play their part from within in the world's transformation of itself' (Ingold, 2011: 6). Both humans and non-humans then produce themselves, one another, and the environment through life. 
Donna Haraway, similarly, critiques Marx and 'hyper-productionism' by arguing that it is a dangerous strategy to see the 'witty agency' only in humans (2004: 66), and 'insists on including nonhuman actors in what would be an otherwise relentlessly human category of that-which-labours' (Wark, 2015:136). It is a crucial change of point of view and maybe even mind set, to see things not just as products of human labour, but as assemblages of all sorts of labours, other things, and lives. Even human bodies are the labouring and assemblage of others, for instance, microbial life, meshed with the life of our companion species - our dogs for instance (Haraway, 2008: 3-44). Thus, things and bodies are amalgams of the living and non-living, even the technological; and their labour: 'chimerical objects, those mash ups of flesh-tech' (Wark, 2015: 136), 'cyborgs, of couplings between organism and machine' (Haraway, 1991: 150). What Haraway does, according to Wark, is take apart the commodity to display not just the human labour - ' $[\mathrm{t}]$ here is a fetishism of labor itself' as the 'man-with-hammer' - but the 'relations of production that the fetish of the commodity obscures' (Wark, 2015: 136-37). As commodities fall apart, under the gaze of the inquirer, to reveal their 'relations of productions', however, so do bodies that first appear as one and autonomous, a 'corporeal fetish' (Haraway, 1997: 142), fall apart to reveal their productions through many lives.

Both commodity and corporeal fetishism make things and life ownable and exchangeable, as we are blinded to their becoming through many processes, labours, and assemblages. Things and bodies seem as standing on their own. For instance, our bodies and the bodies of cereals seem autonomous, yet, Tsing argues, we became what we are today, partially, by labouring on each other's bodies (Tsing, 2012). As we step over the distinction made by Marx between nature, as that which gives the matter, and labour, as that which transforms the matter, Tsing questions the places and ways matter, or nature's raw material, comes into being. Raw materials cannot be taken-for-granted resources for capitalist production; they come into being. Yet they come into being outside of capitalist control, which then takes possession of them (Tsing, 2009, 2015b, 2015a): 'Capitalism makes use of animal digestion and plant photosynthesis without having any clue how to shape these processes, despite the sophisticated engineering of plants and animals. In agribusiness, milk and grain created in these non-capitalist processes are translated into capitalist value' (Tsing, 2015b). The question, then, that Tsing poses is how and where do non-capitalist forms of value enter capitalist forms of production (2015b, 2015a)? She calls these sites at the 'edges of capitalism' 'pericapitalist' sites as they are both in and outside capitalist processes. It is at these sites that "salvage", that is, taking advantage of value produced without capitalist control' happens. These '[s]ites for salvage are simultaneously inside and outside capitalism': 'All kinds of goods and services produced by pericapitalist activities, human and nonhuman, are salvaged for capitalist accumulation' (Tsing, 2015a: 63). 
Furthering the idea of capitalism taking possession of human and nonhuman activities, Moore argues that we cannot think of capitalism as external to nature, or to the 'web of life', which 'is nature as a whole: nature with an emphatically lowercase $n^{\prime}$ (2015: 2, emphasis in the original). Therefore, capitalism itself is 'already co-produced by manifold species, extending even our planet's geological shifts, relations, and cycles' (2015: 3). Nature here, with a lowercase n, includes humans, as co-produced natures between themselves, microbes, bacteria, plants and animals they eat and probably much more. The survival of capitalism, demonstrates Moore, then happens not by destroying nature, but rather by putting life 'to work harder and harder - for free, or at a very low cost'. There is a double movement in this process, first 'new life activity is continually brought into the orbit of capital and capitalist power', second 'humaninitiated projects and processes influence and shape the web of life' (2015: 13). This means that while capitalism is 'co-produced by human and extra-human natures in the web of life' the "law of value" is, in fact, the "law" of Cheap Nature' or the 'ongoing, radically expansive, and relentlessly innovative quest to torn the work/energy of the biosphere into capital (value-in-motion)'. What is, therefore, transformed into value, 'as socially necessary labour-time (abstract social labor) is the "capacity to do work" - by human and extra-human natures' (2015: 14). What Tsing calls 'salvage', the creation of surplus value from life that is produced outside of capitalist control, Moore calls appropriation, as 'those extra-economic processes that identify, secure, and channel unpaid work outside the commodity system into the circuit of capital' (2015: 16).

The following two examples are spaces where the unpaid labour of plant life or spontaneous growth is salvaged or appropriated in order to enter commodity chains. Moreover, these sites are not necessarily outside of capitalist control: the first site is a controlled mono-crop cultivation, where weeds grow through even opposed to capitalist control, yet still enter capital accumulation; the second site is a socialist industrial ruin of capitalist changes, a cynical marker of how life is appropriated for capital accumulation from spaces destroyed by these same processes. While here I focus on the appropriation of the labour of weeds that grow through and in spite of hybrid mono-crops, herbicides, and ruins, it is worth highlighting that plant life is salvaged in the medicinal plant industry not just in its growth as a physical occupation of space, but also through the production of secondary metabolites that create the chemicals that heal ${ }^{12}$.

\footnotetext{
12 In phytochemical terms, the primary metabolites of plants are the compounds that are directly responsible for the plant's normal growth, development, and reproduction, whereas secondary metabolites are those compounds that are not involved in these activities, but have other functions. Etkin argues that early phytochemists saw the compounds produced as secondary metabolites as 'artefacts of metabolism without biological function' (2007: 5). This view,
} 


\section{Spontaneous growth in cultivations}

'They're not weeds, they are medicinal plants', explained to me Nea Spânzu, the head of the family, while showing me some of the species of plants they were collecting. When the medicinal plant company came to the village they lived in, in the early 2000s, they were some of the first to start collecting plants for them. They were often shunned by other villagers for going after weeds, thus they enjoyed stressing the importance of medicinal plants not being weeds. The Spânzu family lived in several small cottages in one compound house. As Nea Spânzu's children married, he built them a new house attached to the previous house's side. They had a horse, cows, pigs, and chicken, they were selling milk and cheese products from house to house, and were thinking about building a polytunnel in the back garden to dry their own plants and thus selling them for more profit. Nea Spânzu was 76 and his wife, Doamna Spânzu, 72 years old. Nea Spânzu used to be a shepherd in a neighbouring county, but during the collectivisation period he handed his sheep over to the C.A.P., the collective farms. He became the shepherd and cheese maker of the C.A.P. in the village while his wife worked on the collective's cultivations. After the fall of the socialist regime, life became harder for the family, until they found work in the newly established medicinal plant production company, working on their field and then collecting medicinal plants from the spontaneous flora. I went plant-picking several times with them during the spring of 2015 , either on foot or in their cart drawn by a horse, with one of their sons or grandsons, depending on who was available.

On one sunny day, we walked to the huge oil seed rape cultivation next to the village. As we turned down a road at the edge of the village, we had to walk alongside a large chicken farm, where chickens were reared inside long hangars, separated from the rest of the world by barbed wire fences. Opposite the chicken farm stretched the yellow flowers of the oil seed rape. When we bent down, we could see how in patches among the oil seed rape grew the trei frați pătați (literally "three spotted brothers", commonly known in English as wild pansy, Viola tricolor). In 2014 Romania cultivated 406,000 ha of oil seed rape (Brassica napus), producing a total of 1,059,000 tons of seeds, $90 \%$ (989,167 tons) of which was sold abroad for biodiesel (M.A.D.R., 2017). While cultivated since the beginning of the $20^{\text {th }}$ century, after joining the EU the cultivation and production of oil seed rape has been growing, as well as the number of farmers who used hybrid seeds from big international companies such as Pioneer, KWS, Bayer,

however, she argues, 'misunderstands the complexity of adaptations that require simultaneous or serial preparedness to compete with a variety of other plants, attract pollinators, and deter herbivores' (2007: 6). Plant labour and life, then again just like human labour and life, is a complex co-production and co-living with other forms of life and their labours. 
Syngenta, Monsanto, together with herbicides, insecticides, and fungicides. Therefore, farmers could shop from an array of herbicides designed specifically to kill of unwanted weeds, among others Viola tricolor (Redacția Sănătatea Plantelor, 2017; DuPont $®$ România 2017), together with specific oil seed rape hybrids that were tolerant to such herbicides (Gazeta de Agricultură, 2012). Whether the farmer of this particular oil seed rape was not diligent in spreading herbicides or the Viola tricolor survived it, the Spânzu family recognised them not as weeds to be killed but as medicinal plants that were valuable as resources for human use.

Collecting medicinal plants or weeds from different cultivations was indeed a common story within the medicinal plant industry. A medicinal plant company owner told me that his people once gathered 80 tonnes of horsetail from within different corn cultivations. The horsetail could not be killed off by any herbicide, so the corn farmers were thankful for the weeding. Other collectors have, for instance, explained how the most beautiful and luscious dandelions grew among the lucerne fields of the villagers. Thus, while for some the spontaneously growing plants within cultivations were weeds they needed to get rid of, others recognised the companionship between human sown plants and weeds and remembered that dandelion grows lush among lucerne. It is not Nature that is able to grow within sprayed fields of mono-crops but spontaneous flora, which then is collected to enter other processes of capital accumulation.

\section{Spontaneous growth in ruins}

When I first got on the horse drawn carriage of the Spânzu family, we took a tight, concrete road towards a nearby city in order to gather elderflowers. We talked about how the family used to take the cart to forage a lot more often, even camping for several days sometimes, but these days, with so many cars, it is a suicide mission to go too far away. Doamna Spânzu was also keenly attentive to the plants growing at the side of the road, checking both what plants have started to flower, but also looking for good gathering areas, where plants grew in thick, easily harvestable patches. We went to the ruins of an old socialist orchard and flower growing facility. At the edge of the county capital, the ruins of the huge concrete buildings were overgrown by vegetation, and we had to be careful not to step on the broken glass, leftovers of greenhouses. We went to harvest elderflowers from the unkempt bushes that grew unaffected by the slow destruction of the buildings around them. Among the elder and the sparse wild rose bushes, we also found thick patches of lavishly growing stinging nettles (Urtica diorica), to be remembered, argued Nea Spânzu, to come back with a scythe, because it is easily cut. Within the ruined buildings I could hear other

people perhaps looking for plants and scrap metal, while we had to be careful not to be seen or caught by the guard. We were trespassing. 
Industrial ruins can be seen, especially in Eastern Europe, as the result of ingrained corruption or failed economic practices (Iatridis and Hopps, 1998; Thirkell, Petkov, and Vickerstaff, 1998; Kirk, 2003), however, they are just as much part of economic growth, seen as the leftover footprints of the chase of ever more profitable capital accumulation (Edensor, 2005). Edensor argues against a view of industrial ruins as wastelands where nothing happens and nothing is made, through showcasing the positive roles they take on. Industrial ruins, he demonstrates, not only highlight the failure of an idea of endless prosperity and growth, but become playgrounds, stage sets, shelters for humans, sanctuary for animals, and they also embody memory. ${ }^{13}$ Here, in this abandoned orchard, nevertheless, there was something more cynical happening. As '[a]bandoned buildings tend to be rapidly stripped of valuable assets' (Edensor, 2005: 5), this socialist ruin of capitalism became re-appropriated for capital accumulation as scrap metal, planted elder bushes, and spontaneously growing nettles were reinserted into commodity supply-chains. As mushrooms in the 'ruined industrial city and abandoned or partially abandoned site of modern agribusiness or industrial forestry', weeds became commodities too through the 'scrounging economy' that looks for treasures in ruins (Tsing, 2014: 89-90).

\section{Scrounging}

While the appropriation of plant labour depended on the Spânzu family as scroungers, their role within the accumulation process was ambiguous. The engineer working at the collection centre for whom the Spânzu family harvested told me that Nea Spânzu and his wife were indispensable when it came to roaming the pastures, hills, and mountains for plants because they knew the landscape so well. They would also not be able to sit in an 8-hour job. 'They say they are not Gypsies', he explained, 'but they have a brown complexion and that need of freedom that makes them unable to sit 8 hours in a place'. While the pair did enjoy and love the movement in and the attentiveness to the landscape needed to find the plants, they used to work on cultivations as well, a job they agreed was less enjoyable because even though they worked really hard, they were never appreciated. ${ }^{14}$ They also lived on the street some of the company employees called the 'Gypsy Lane'. Through 'brownness' and freedom, the gaze 'recognised' the two Spânzu elders as 'Gypsies'. This gaze means that people, and researchers alike, recognise some people as Roma because of the categories we

\footnotetext{
${ }^{13}$ For more on the importance of ruins as sites of memory in Romania, see Pusca (2010).

14 Picking in forests as a form of freedom was familiar to the matsutake pickers Anna Tsing worked with: 'He went on to say that he prefers mushroom picking to a steady job with a good income - he was a welder - because of the freedom' (Tsing, 2015a: 94).
} 
attach to Roma-ness, a gaze that follows Roma people all their lives and often becomes internalised (Kovács, 2009: 37). Nea Spânzu, on the other hand, enjoyed the occasional scornful remarks on account of one of his sons in law, 'a Gypsy boy, but hardworking'.

Emigh, Fodor, and Szelényi (2001) argue that the racialisation of poverty became the outcome of a classificatory struggle in Eastern Europe after the revolution. Poverty as a social phenomenon became 'presented as if it were racial, not social, and therefore, as if it were genetically and biologically determined'. Racialisation then, they argue, was 'a strategy used by the positively privileged ethnic group to keep themselves out of the category "poor" and/or to blame the poor for their own poverty' (2001: 5). Kinds of labours, therefore, were not devoid of association with social class. Foraging was seen by many employees in different companies to whom I talked to as done by Roma, whether foragers thought about themselves as Roma or not. A desire for 'freedom' together with a seemingly 'irresponsible' attitude towards life were often mentioned as particularities of foragers and the Roma. In the same breath that Roma foragers were admired for knowing more plants and more foraging places than anyone else, they would be reprimanded for not being careful enough when harvesting, by snatching plants with roots, or leaving plants in sacks for too long, in explanations given to me about how foraging works. This mixture of racialized and romanticised images played out in the day to day realities of the people labouring at the edges of capitalist salvage.

Race (and gender and nationality) differences are, therefore, in the medicinal plant industry part of 'figurations of labour' and 'are needed to tell effective stories about contemporary capitalism' (Tsing, 2009: 154). Indeed, I internalised the disapproving narratives of how foragers rip (smulg in Romanian) plants with their roots - narratives that were often retold with disdain whether or not the ripping of the plant affected its reproduction - so well during my fieldwork that I caught myself judging my companions for ripping the Viola tricolor out in the middle of an intensive oil rape cultivation. Indeed, the Spânzu family did often rip plants with roots or pull, for instance, common hawthorn flowers (Crataegus monogyna), with one rip off their branches. Collection for them was a job that needed to be done quickly to be lucrative, constantly monitoring the fullness and number of the sacks and the time left until the end of the day.

Scrounging, scavenging, or foraging are activities that find things and beings to be inserted into capitalist accumulation. As opposed to cultivators who have to know plants through how to grow them, foragers had to know them through where they grew: 'Where an orientation to farming encourages us to imagine a one-to-one relationship between humans and our food crops, wild 
mushrooms [or spontaneously growing plants] press us into multispecies ecologies in which control may be impossible' (Tsing, 2014: 90). While foragers cannot control where plants grow, they can be attentive to the multispecies ecologies that they grew in. Thus, they were attentive to plants growing on roadsides, dandelions growing fat amongst the lucerne, wild pansy among the large rape fields, or thick patches of nettles weeding over ruins. In turn, then, capitalist accumulation appropriates the 'cheap' attentiveness of those scrounging, an activity 'especially appealing to those without other resources' (Tsing, 2014: 94), like those who lost their work in the C.A.P. after the fall of socialism and could not find other means of subsistence. For scroungers there is no difference then between 'pristine nature' or 'trashed" landscape' (Bonta, 2010: 143), rather as their survival depended on selling, thus gathering quickly and embracing the multispecies ecology of life in its 'spontaneity' as it was, they had to salvage plants from where they could find them. It is through the energy and work-for-survival of the scroungers that the energy and work-for-survival of weeds became appropriated for capitalist projects.

\section{Nature and the spontaneous flora again}

While plants from the spontaneous flora end up on supermarket and nature shop shelves as natural products, within the scientific practice of plant chemistry, the chasing of Nature continues. In laboratories, spontaneous flora is not devoid of ambiguity, moreover, its naturalness itself is often questioned. Chemists and pharmacologists working for medicinal plant product companies at conferences sometimes criticised plants being gathered and cultivated in conditions that were not ecological, and therefore, they argued, not natural conditions. Indeed, they explained, only those products and/or ingredients that were labelled as ecological were truly 'natural', because other plants could be affected by pesticides, fertilisers, or had added aromas and colourants. 'Ecological' then became synonymous with 'natural' as the foundations for health claims. Gathering ecological plants not only involved proving that their gathering did not affect the environment and the ecosystem in a negative way, but they had to come from well-defined, certified areas regularly checked and authorised by a variety of institutions such as the Romanian Academy (Ecoinspect, 2015).

Some companies even waged war against ingredients coming from the spontaneous flora, as they could not be controlled properly. At one conference, the representatives of a company promoted the importance of the soil and environment that medicinal plants come from, advocating their ecological cultivations. They opposed gathering from the spontaneous flora and quoted an experiment they conducted with plants 'polluted' by dog urine, and how terribly 
that altered the plants' chemical composition. Similarly, they argued, one could not control the number of reagents (artificial fertilisers and pesticides) that could affect plants gathered from the uncontrolled and un-ecological spontaneous flora, especially when plants were gathered from next to or even within large agricultural cultivations. Whether any pesticides, herbicides, fertilisers, or dog urine changed the chemical composition of the plants I mentioned here, I do not know. Nevertheless, some producers argued that it was of utmost importance to control the whole process of growing and harvesting in order to have good quality plants. 'Natural' as healthy for humans did not mean untouched by humans in these cases, rather the opposite, it became associated with the rigorous control of the plants' origins and their chemical compounds.

While in some laboratories the spontaneous flora was deemed notnatural, because it was not seen as healing for human bodies, the spontaneous flora entered capitalist processes as natural products on shelves. As weeds grow in cultivations and break up the concrete pavement of abandoned orchards, nature, as life, literally works through the zones of capitalism. As they become inserted into capitalist production, they shape human bodies in intimate ways as they become ingested through teas, pills, tinctures, or syrups. Yet somewhere along the process, the not always so Natural lifeworlds of plants are severed. Moore argues that capitalism, through symbolically severing the relation between humanity and its species-environment relation, creates from the term 'natural' a 'crucible of legitimation' (2015: 11). Marx refers to things as alienable from man, meaning that they 'are in themselves external to man' (Marx, 1990, I:182) and thus freely exchangeable. As they stop having use-value for those who sell them, they become comparable to any other commodity. Tsing argues, that in a capitalist logic of commodification the process of alienation means that 'things are torn from their lifeworlds to become objects of exchange', alienation, 'which becomes a potential attribute of nonhumans as well as humans' (2015a: 121): 'This history has inspired investors to imbue both people and things with alienation, that is, the ability to stand alone, as if the entanglements of living did not matter', they become 'mobile assets' (2015a: 5). Humans and nonhumans have then their properties stripped to be comparable and therefore exchangeable with any other thing on the market. For medicinal plants, this means that the wild pansy coming from its multispecies relation with the hybrid oil seed rape and the nettle that cracked through the pavement of the ruined orchard, on the shelves, stripped by their lifeworlds, become synonymous with Nature, that abstract concept that legitimises natural products.

On shelves and in promotional materials medicinal plants then became attached to abstract images of the traditional plant lore of ancestors or peasants rather than the image of the Spânzu family as they put together their livelihoods from plant picking, owning their own animals, selling milk and home-made 
cheese, and planning to build facilities to help them dry their own plants and thus acquiring a larger profit by selling dried plants rather than fresh ones. Similarly, Narotzky summarises the peasant debates between the 1960s and the 1980s that challenged classical Marxist theories of the proletarianization as a concrete historical development and instead of describing a 'universal ("natural") peasant logic seeking simple reproduction', 'the debate explored the complex forms of surplus extraction that have been historically present in societies dominated by powerful actors of capital accumulation' (2016: 311). This means that peasants never did simply seek a simple reproduction of value (producing only as much as the household needs) as opposed to the capitalists who were looking for expanding accumulation. Rather, it means that throughout history as well as today, peasants had to negotiate the complexities of both reproductive labour and market accumulation. The production of things for the household was negotiated together with wage labour and entrepreneurial activities (2016:310), as the Spânzu family has done. This recalls Tsing's call to pay attention to the 'flawed protagonists' of supply chain capitalism, the 'politically ambiguous, liminal figures, caught within the contradictions between varied forms of hierarchy and exclusion' (2009: 154).

Through the two spaces of collecting from the spontaneous flora of the oil seed rape cultivation and the ruined socialist orchard with the Spânzu family, I wanted to highlight the tension between the spontaneous flora and scroungers on the ground and Nature with its ancestral peasants on the supermarket and nature shop shelves. I found that the term spontaneous flora brings to the forefront the appropriation of the reproductive labour of weeds that grow either outside or even against human control. Thus, the labour of growth through and against capital accumulation becomes part of other capitalist processes through the work of those who are themselves partially outside of these processes. Capital is, therefore, accumulated through the cheap labour of plants and people sustained by processes outside of capitalist production such as the photosynthesis of plants or the household work that is part of maintaining the livelihoods of the Spânzu family.

\section{REFERENCES}

Bensaude-Vincent, Bernadette. (2007). Reconfiguring Nature through Syntheses: From Plastics to Biomimetics, in The Artificial and the Natural: An Evolving Polarity, edited by Bernadette Bensaude-Vincent and William R. Newman, 293-312. MIT Press. 
Bensaude-Vincent, Bernadette, and Isabelle Stengers. (1996). A History of Chemistry. 1st edition. Cambridge: Harvard University Press.

Bogdal, Klaus-Michael. (2011). Europa erfindet die Zigeuner: Eine Geschichte von Faszination und Verachtung. 5th ed. Berlin: Suhrkamp Verlag.

Bojor, Ovidiu, and Răducanu Dumitru. (2007). Plante și miresme biblice: hrană pentru suflet și trup. București: Fiat Lux.

Bonta, Mark. (2010). Ornithophilia: Thoughts on Geography in Birding. Geographical Review 100 (2): 139-51.

Borloveanu, Mariana. (2014). Leacuri mănăstirești: terapii pentru trup și suflet. București: Editura Lumea Credinței.

Cassidy, Rebecca. (2007). Introduction: Domestication Reconsidered, in Where the Wild Things Are Now: Domestication Reconsidered, edited by Rebecca Cassidy and Molly Mullin, 1- 25. Berg.

Cassidy, Rebecca, and Molly Mullin, eds. (2007). Where the Wild Things Are Now: Domestication Reconsidered. Berg.

Chirilă, Pavel, and Mihai Valică. (2009). Spitalul creștin: introducere în medicina pastorală. Editura Christiana.

Cosma, Valer Simion. (2017). Inventarea țăranului în cultura română transilvăneană (Secolul al XIX-Lea), in La Graniţa Dintre Științe: Istorie, Mentalități, Imaginar, edited by Ovidiu Ghitta and Gheorghe Negustor. Cluj Napoca: Argonaut/Mega.

Dumitrescu, Florin. (2015). Tradții la superofertă. între socoteala din agenție și cea de la raft. Cartier.

Edensor, Tim. (2005). Industrial Ruins: Space, Aesthetics and Materiality. Bloomsbury Academic.

Emigh, Rebecca Jean, Éva Fodor, and Iván Szelényi. (2001). The Racialization and Feminization of Poverty, in Poverty, Ethnicity, and Gender in Eastern Europe During the Market Transition, edited by Rebecca Jean Emigh and Iván Szelényi, 1-32. Greenwood Publishing Group.

Etkin, Nina L. (2007). Edible Medicines: An Ethnopharmacology of Food. University of Arizona Press.

Haraway, Donna Jeanne. (1991). A Cyborg Manifesto: Science, Technology, and SocialistFeminism in the Late Twentieth Century, in Simians, Cyborgs, and Women. The Reinvention of Nature, 149-82. Routledge.

_-—. (1997). Modest_Witness@Second_Millennium.FemaleMan_Meets_OncoMouse: Feminism and Technoscience. New York: Routledge.

. (2004). The Promises of Monsters: A Regenerative Politics for Inappropriate/d Others, in The Haraway Reader, 63-125. New York and London: Routledge.

- - 2008. When Species Meet. University of Minnesota Press.

Harvey, David. (2010). A Companion to Marx's Capital. Verso.

Hedley Brooke, John. (2007). Overtaking Nature? The Changing Scope of Organic Chemistry in the Nineteenth Century. in The Artificial and the Natural: An Evolving Polarity, edited by Bernadette Bensaude-Vincent and William R. Newman, 275-92. MIT Press. 
Iatridis, Demetrius S., and June G. Hopps. (1998). Privatization in Central and Eastern Europe: Perspectives and Approaches. Greenwood Publishing Group.

Ingold, Tim. (2011). Being Alive: Essays on Movement, Knowledge and Description. Routledge.

Kirk, John. (2003). Mapping the Remains of the Postindustrial Landscape. Space and Culture 6 (2): 178-86.

Kocze, Angela, and Nidhi Trehan. (2009). Postcolonial Racism and Social Justice, in Racism Postcolonialism Europe, edited by Graham Huggan and Ian Law. Liverpool: Liverpool University Press.

Kovács, Éva Judit. (2009). The 'Fact' of Gypsyness. A Case from Hungary. Nevi Sara Kali. Roma Women's Journal, 1: 30-44.

Kürti, László. (2005). Shamanism - Neo (Eastern Europe), in The Encyclopedia of Religion and Nature, edited by Bron Taylor, Volume 2:1529-31. Thoemmes Continuum.

Latour, Bruno. (1987). Science in Action: How to Follow Scientists and Engineers Through Society. Harvard University Press.

- - - (2004). Politics of Nature. Harvard University Press.

-_- (2005). Reassembling the Social: An Introduction to Actor-Network-Theory. OUP Oxford.

Lázár, Imre. (2006). Táltos Healers, Neoshamans and Multiple Medical Realities in Hungary, in Multiple Medical Realities: Patients and Healers in Biomedical, Alternative and Traditional Medicine, edited by Helle Johannessen and Imre Lázár, 35-52. New York: Berghahn Books.

Lorimer, Jamie. (2015). Wildlife in the Anthropocene: Conservation after Nature. University of Minnesota Press.

Marder, Michael. (2011). Plant-Soul: The Elusive Meanings of Vegetative Life. Environmental Philosophy, 8 (1): 83-99.

Marx, Karl. (1990 [1867]). Capital. A Critique of Political Economy. Translated by BenFowkes. Vol. I. Penguin Books.

Mihăilescu, Vintilă. (2013). Scutecele națiunii și hainele împăratului. Note de antropologie publică. 2nd ed. Polirom.

-——. (2015). Apologia Pîrleazului. Polirom.

Moore, Jason W. (2015). Capitalism in the Web of Life: Ecology and the Accumulation of Capital. Verso.

Narotzky, Susana. (2016). Where Have All the Peasants Gone? Annual Review of Anthropology 45 (1): 301-18.

Povedák, István. (2014). The Monk and the White Shaman, in Religion, Culture, Society. Yearbook of the MTA-SZTE Research Group for the Study of Religious Culture, edited by Gábor Barna, 95-114. Szeged.

Pusca, Anca. (2010). Industrial and Human Ruins of Postcommunist Europe. Space and Culture 13 (3): 239-55.

Thirkell, John E. M., Krastyu Petkov, and Sarah Vickerstaff. (1998). The Transformation of Labour Relations: Restructuring and Privatization in Eastern Europe and Russia. Oxford University Press.

Tong, Diane, ed. (1998). Gypsies: An Interdisciplinary Reader. New York: Taylor \& Francis. 
Tsing, Anna Lowenhaupt. (2005). Friction: An Ethnography of Global Connection. Princeton University Press.

. (2009). Supply Chains and the Human Condition. Rethinking Marxism 21 (2): 148-76.

- - - (2012). Unruly Edges: Mushrooms as Companion Species. Environmental Humanities 1: 141-54.

-_- (2014). Blasted Landscapes (And the Gentle Arts of Mushroom Picking), in The Multispecies Salon, edited by Eben Kirksey, 87-109. Durham: Duke University Press.

- - - (2015a). The Mushroom at the End of the World: On the Possibility of Life in Capitalist Ruins. Princeton University Press.

-_- (2015b). Salvage Accumulation, or the Structural Effects of Capitalist Generativity - Cultural Anthropology. Cultural Anthropology. March 30, 2015.

Wark, McKenzie. (2015). Molecular Red: Theory for the Anthropocene. Verso.

\section{List of other sources}

Descopera Natura. (2013). https://www.youtube.com/watch?v=y_ZEMTnrFIA. [Accessed 15.05.2018].

DuPont® România. (2017). Catalog DuPont. 2017. https://bit.ly/2LVVhfC. [Accessed 15.05.2018].

Ecoinspect. 2015. Informare Privind Operatorii Care Colectează Specii Din Flora Spontană. https://www.ecoinspect.ro. [Accessed 10.01.2018].

Enciclopedia Plantelor - Introducere. (2013).

http://www.youtube.com/watch?v=QVXcHN_lM98\&feature=youtube_gdata_play er. [Accessed 15.05.2018].

Gazeta de Agricultură. (2012). Soluții inovatoare în cultura rapiței de toamnă. https://bit.ly/20qDXAX. [Accessed 15.05.2018].

M.A.D.R., Ministerul Agriculturii și Dezvoltării Rurale. (2017). Rapiță Pentru Ulei.

http://www.madr.ro/culturi-de-camp/plante-tehnice/rapita-pentru-ulei.html. [Accessed 15.05.2018].

Redacția Sănatatea Plantelor. (2017). Fără buruieni în cultura de rapiță, cu 'pachetele iscusite' de la ALCEDO. https://www.sanatateaplantelor.ro/fara-buruieni-incultura-de-rapita-cu-pachetele-iscusite-de-la-alcedo/. [Accessed 2.08.2017]. 